\title{
GRIN2A wt Allele
}

National Cancer Institute

\section{Source}

National Cancer Institute. GRIN2A wt Allele. NCI Thesaurus. Code C98147.

Human GRIN2A wild-type allele is located in the vicinity of 16p13.2 and is approximately $429 \mathrm{~kb}$ in length. This allele, which encodes glutamate receptor ionotropic, NMDA 2A protein, plays a role in both NMDA binding and ion transport. Mutations in the gene are associated with epilepsy, ovarian cancer and melanoma. 